\title{
Efektivitas Media Model Pembentukan Urin terhadap Hasil Belajar Siswa pada Konsep Sistem Ekskresi
}

\section{Media Effectiveness of Urine Formation Model on Student Learning Outcomes in the Concept of Excretion Systems}

\author{
Yuyun Yunengsih ${ }^{1 *}$, Mimin Nurjhani $K^{1}$, Fransisca Sudargo $^{1}$ \\ ${ }^{1}$ Departemen Pendidikan Biologi, Fakultas Pendidikan Matematika dan Ilmu Pengetahuan Alam, Universitas Pendidikan \\ Indonesia \\ *Email Korespondensi: yuyunyunengsiiih@gmail.com
}

doi: https://doi.org/10.29405/j.bes/2295-1032050

Received: 9 September 2018 | Accepted: 2 Desember 2018 | Published: 31 Desember 2018

\begin{abstract}
Abstrak
Background: Proses dalam pembelajaran merupakan proses komunikasi yang di dalamnya melibatkan tiga komponen pokok, yaitu, komponen pengirim pesan, penerima pesan dan pesan pesan itu sendiri. Namun, tidak jarang terjadi kegagalan komunikasi di dalam proses pembelajaran. Hasil Observasi dalam penelitian ini menunjukkan bahwa pada kenyataannya dalam proses pembelajaran di kelas guru lebih mendominasi dan masih menggunakan metode ceramah, sehingga siswa cenderung pasif, bosan dan pada akhirnya tidak memiliki ketertarikan terhadap pembelajaran biologi. Untuk menghindari kegagalan komunikasi, maka guru perlu menyusun strategi pembelajaran, yang salah satunya adalah dengan memanfaatkan media. Penelitian ini bertujuan untuk mengukur efektivitas penggunaan media model dalam proses pembelajaran. Metode: Penelitian eksperimen ini menggunakan empat macam instrument yaitu lembar observasi, test berupa pretest-posttest, kuesioner, dan lembar wawancara. Adapun siswa yang terlibat dalam penelitian ini yaitu sebanyak 72 siswa dari dua kelas yang dijadikan sebagai kelas eksperimen dan kelas kontrol. Kelas eksperimen pembelajarannya menggunakan media model pembentukan urin sedangkan kelas kontrol menggunakan pembelajaran konvensional berupa ceramah ditambah dengan powerpoint. Hasil: Hasil penelitian menunjukkan bahwa pelaksanaan pembelajaran telah sesuai dengan perencanaan pada RPP. Selain itu, hasil belajar siswa kelas eksperimen lebih tinggi dibandingkan kelas kontrol, dan media mendapatkan respon positif oleh beberapa pihak, sehingga dapat dikatakan bahwa pembelajaran menggunakan media model pembentukan urin efektif dalam pembelajaran sistem ekskresi. Kesimpulan: Hasil penelitian tersebut menunjukkan bahwa pembelajaran menggunakan media model pembentukan urin efektif digunakan dalam membelajarkan materi system ekskresi.
\end{abstract}

Kata kunci: Efektivitas; Media Model; Hasil Belajar; Sistem Ekskresi.

\section{Abstract}

Background: The process in learning is a communication process which involves three main components, namely, the sender of the message, the recipient of the message and the message message itself. However, communication failure is not uncommon in the learning process. Observation results in this study indicate that in reality in the learning process in the classroom teachers dominate and still use the lecture method, so students tend to be passive, bored and ultimately have no interest in learning biology. To avoid communication failure, the teacher needs to develop learning strategies, one of which is using the media. Methods: In general, this study aims to measure the effectiveness of using media models in the learning process. This experimental research uses four types of instruments, namely observation sheets, pretestposttest tests, questionnaires, and interview sheets. The students involved in this study were as many as 72 students from two classes which were used as the experimental class and the control class. The learning experimental class uses a urine formation model while the control class uses conventional learning in the form of lectures plus powerpoint. Results: The results of the study indicate that the implementation of learning is in accordance with the planning in the lesson plan. In addition, the learning outcomes of the 
experimental class students are higher than the control class, and the media get a positive response by several parties, so that it can be said that learning using media is a model of urine formation effective in learning excretion systems. Conclusions: The results of the study indicate that learning using a urine formation model is effectively used in learning excretory system material.

Keywords: Effectiveness; Model Media; Learning Outcomes; Excretion System.

Cara Sitasi: Yunengsih, Y., Nurjhani, M., \& Sudargo, F. 2019. Efektivitas Media Model Pembentukan Urin terhadap Hasil Belajar Siswa pada Konsep Sistem Ekskresi. BIOEDUSCIENCE, 2(2): 95-103. Doi: https://doi.org/10.29405/j.bes/2295-1032050

(C) 2018 Oleh authors. Lisensi Bioeduscience, Uhamka, Jakarta. Artikel ini bersifat open access yang didistribusikan di bawah syarat dan ketentuan Creative Commons Attribution (CC BY) license. (http://creativecommons.org/licenses/by/4.0/).

\section{PENDAHULUAN}

Dalam suatu proses komunikasi selalu melibatkan tiga komponen pokok, yaitu komponen pengirim pesan atau guru, komponen penerima pesan atau siswa, dan komponen pesan itu sendiri yang biasanya berupa materi pelajaran. Terkadang dalam proses pembelajaran terjadi kegagalan komunikasi. Untuk menghindari semua itu, maka guru dapat menyusun strategi pembelajaran dengan memanfaatkan berbagai media dan sumber belajar (Sanjaya, 2007).

Kehadiran media mempunyai arti yang cukup penting dalam proses belajar mengajar, karena dalam kegiatan tersebut ketidakjelasan materi dapat dibantu dengan menghadirkan media sebagai perantara. Media pembelajaran dapat meningkatkan efektivitas dan efisiensi penyampaian informasi, meningkatkan semangat dan gairah belajar siswa, dan mencegah kebosanan. Kerumitan bahan yang akan disampaikan kepada anak didik dapat disederhanakan dengan bantuan media. Media dapat mewakili apa yang kurang mampu guru ucapkan melalui kata-kata atau dengan kalimat tertentu. Bahkan keabstarakan bahan dapat dikonkretkan dengan kehadiran media. Dengan demikian, anak didik akan lebih mudah mencerna bahan dari pada tanpa bantuan media. Disini nilai praktis media terlihat, yang bermanfaat bagi siswa dan guru dalam proses belajar mengajar (Djamarah et al., 2010).
Materi biologi akan lebih mudah dicerna pada memori peserta didik melalui bantuan media. Manfaat penggunaan media dalam pembelajaran biologi antara lain dapat menanamkan konsep dasar dengan lebih konkrit dan realitas terutama untuk mengatasi konsep biologi yang abstrak. Salah satu materi yang dalam biologi yang bersifat abstrak adalah system eksresi. Pada materi proses pembuatan urin, diperlukan suatu pemecahan masalah dalam mempelajari materi tersebut. Salah satu bentuk pemecahannya adalah dengan mengembangkan media pembelajaran yang dapat menunjukkan proses terbentuknya urin yang disebut media model pembentukan urin.

\section{MATERI DAN METODE}

Pendekatan yang digunakan dalam penelitian ini adalah kuantitatif dengan desain penelitian Quasi Experimental Design yaitu Nonequivalent Control Group Design. Sample yang digunakan adalah 72 siswa SMA kelas XI yang terdiri dari dua kelas yaitu kelas XII IPA-7 sebanyak 36 siswa sebagai kelompok eksperimen dan kelas XII IPA-4 sebanyak 36 siswa sebagai kelompok kontrol. Kelompok eksperimen pembelajarannya menggunakan media model pembentukan urin sedangkan kelompok kontrol menggunakan pembelajaran konvensional berupa ceramah ditambah slide powerpoint.

Instrumen yang digunakan dalam penelitian ini adalah lembar observasi yang digunakan 
untuk mengukur efektivitas berdasarkan kesesuaian perencanaan dan pelaksanaan pembelajaran, instrumen tes berupa pretes dan posttes yang digunakan untuk mengukur hasil belajar setelah diberikan perlakuan baik pada kelompok eksperimen maupun kelompok kontrol. Instrumen kuesioner bertujuan untuk menjaring respon atau tanggapan terhadap media yang telah dibuat dan instrumen lembar wawancara untuk menjaring informasi mengenai kekurangan, kelebihan serta rekomendasi media model pembentukan urin.

Analisis data lembar observasi penilaiannya didasarkan pada kriteria yang terdapat pada lembar observasi. Setiap tanda checklist $(\sqrt{ })$ pada kolom ya berskor 1 poin sedangkan pada kolom tidak berskor 0 . Hasil skoring dari setiap observer dijumlahkan, dipersentasekan dan diinterpretasikan untuk mengetahui efektivitas kegiatan pembelajaran yang dilakukan. Analisis data test (pretest-posttest) penilaian untuk soal pilihan ganda yaitu setiap soal benar mendapat nilai 1 dan setiap soal salah mendapat nilai 0 . Nilai yang diperoleh untuk setiap item kemudian dijumlahkan. Nilai yang diperoleh kemudian di konvensikan ke dalam skala nilai 100. Untuk mengetahui peningkatan hasil belajar siswa setelah diberikan perlakuan, maka data pretest dan data posttest dihitung Gainnya yaitu selisih antara skor posttest dengan skor pretest, kemudian dihitung nilai Gain ternormalisasi $(\mathrm{N}$ Gain). Analisis data pretest, posttest dan N-Gain dilakukan dengan menggunakan software IBM SPSS Statistics 21.0. Data kuesioner siswa dan guru di analisis berdasarkan hasil skoring dari setiap aspek yang terdapat pada kuesioner efektivitas kegiatan pembelajaran. Data lembar wawancara yang telah dikumpulkan akan di generalisasikan dari masing-masing aspek. Kemudian disajikan melalui interpretasi dan diurai menjadi sebuah deskripsi.

\section{HASIL}

Data hasil observer 1 jumlah skor yang didapat yaitu 17 dari jumlah seluruh aspek sebanyak 17, jika di persentasekan yaitu sebesar 100\%. Berdasarkan data hasil lembar observasi dari dua orang observer akan disajikan pada Tabel 1. Dengan kata lain kegiatan pembelajaran Efektif karena pelaksanaan pembelajaran telah sesuai dengan perencanaan pada RPP. Pengelolaan waktu yang didapat observer 1 yaitu sebanyak 177 menit. Waktu yang didapatkan ketika pelaksanaan pembelajaran ini tidak sesuai dengan waktu yang direncanakan pada RPP yaitu sebanyak 135 menit atau tiga jam pelajaran, sehingga dapat dikatakan pengelolaan waktu Tidak Efektif selama pembelajaran dengan menggunakan media model pembentukan urin karena memakan waktu yang lama yaitu penambahan 42 menit dari total alokasi waktu pada RPP.

Tabel 1. Rekapitulasi Hasil Lembar Observasi

\begin{tabular}{lcc}
\hline \multicolumn{1}{c}{ Aspek yang } & \multicolumn{2}{c}{ Hasil Perolehan } \\
\cline { 2 - 3 } \multicolumn{1}{c}{ diamati } & Observer 1 & Observer 2 \\
\hline Aspek ke 1-4 & Skor : 17 & Skor : 14 \\
Persentase & $100 \%$ & $82,35 \%$. \\
Interpretasi & Efektif & Efektif \\
Aspek ke 5 & 177 menit & 187 menit \\
Interpretasi & Tidak Efektif & Tidak Efektif \\
\hline
\end{tabular}

Adapun data hasil observer 2, jumlah skor

Tabel 2. Rekapitulasi Hasil Pretest, Posttest, $N$-Gain Kelas Eksperimen dan Kelas Kontrol

\begin{tabular}{lcccccc}
\hline \multirow{2}{*}{ Aspek Peninjau } & \multicolumn{2}{c}{ Pretest } & \multicolumn{2}{c}{ Posttest } & \multicolumn{2}{c}{$\boldsymbol{N - G a i n}$} \\
\cline { 2 - 7 } & Eksperimen & Kontrol & Eksperimen & Kontrol & Eksperimen & Kontrol \\
\hline Jumlah Siswa & 36 & 36 & 36 & 36 & 36 & 36 \\
Nilai Rata-rata & 64,88 & 65,22 & 83,91 & 79,83 & 0,54 & 0,42 \\
Nilai Minimal & 40,00 & 27,00 & 53,00 & 40,00 & 0,13 & 0,10 \\
Nilai Maksimal & 87,00 & 87,00 & 100,00 & 100,00 & 1,00 & 1,00 \\
Standar Deviasi & 11,12 & 13,88 & 11,67 & 13,56 & 0,23 & 0,21 \\
\hline
\end{tabular}

dijumlahkan dan dipersentasekan. Skor yang didapat diinterpretasikan untuk mengetahui yang didapat yaitu 14 dari jumlah seluruh aspek sebanyak 22 dan jika di persentasekan yaitu 
sebesar $82,35 \%$. Pengelolaan waktu yang didapat observer 2 yaitu sebanyak 187 menit lebih banyak dibandingkan dengan waktu yang didapat pada observer 1. Waktu yang didapatkan ketika pelaksanaan pembelajaran ini tidak sesuai dengan waktu yang direncanakan pada RPP yaitu sebanyak 135 menit atau tiga jam pelajaran, sehingga dapat dikatakan pengelolaan waktu Tidak Efektif. Rekapitulasi hasil pretest, posttest dan $N$-Gain pada kelas eksperimen dan kelas kontrol akan disajikan pada Tabel 2.

\section{Pengetahuan Siswa (Pretest) dan (Posttest)}

Berdasarkan data pada Tabel 2, dapat diketahui hasil belajar siswa pada kelas eksperimen dan kelas kontrol yang diperoleh melalui pretest menunjukkan bahwa pengetahuan awal siswa pada konsep sistem ekskresi pada ginjal manusia masih rendah. Hal ini terlihat dari nilai rata-rata pada kedua kelas tersebut yaitu 64,88 pada kelas eksperimen dan 65,22 pada kelas kontrol. Nilai rata-rata pretest kelas kontrol lebih tinggi dibandingkan nilai rata-rata pretest kelas eksperimen. Adapun nilai minimal yang diperoleh pada kelas eksperimen yaitu sebesar 40,00, sedangkan pada kelas kontrol nilai minimal sebesar 27,00. Sedangkan nilai maksimal yang diperoleh baik pada kelas eksperimen maupun kelas kontrol yaitu sebesar 87,00 . Setelah diberikan perlakuan, hasil belajar siswa kedua kelas tersebut menjadi lebih baik dibandingkan hasil pada saat pretest. Hal ini dilihat dari adanya peningkatan nilai rata-rata posttest yaitu sebesar 83,91 dari nilai rata-rata pretest 64,88 pada kelas eksperimen dan nilai rata-rata posttest sebesar 79,83 dari nilai rata-rata pretest 65,22 pada kelas kontrol.

Peningkatan hasil belajar pada saat posttest tidak hanya dari nilai rata-rata melainkan nilai maksimal dan minimalpun mengalami peningkatan. Nilai minimal yang diperoleh pada kelas eksperimen yaitu sebesar 53,00 dari nilai minimal yang diperoleh pada saat pretest 40,00 . Sedangkan nilai minimal yang diperoleh pada kelas kontrol yaitu sebesar 40,00 dari nilai minimal yang diperoleh pada saat pretest 27,00.
Adapun nilai maksimal yang diperoleh pada kelas eksperimen dan kelas kontrol yaitu sebesar 100 , lebih besar dibandingkan dengan perolehan nilai maksimal pada saat pretest 87,00 .

Berikut ini akan disajikan data perbandingan nilai rata-rata pretest dan posttest pada kelas eksperimen dan kelas kontrol pada Gambar 1.

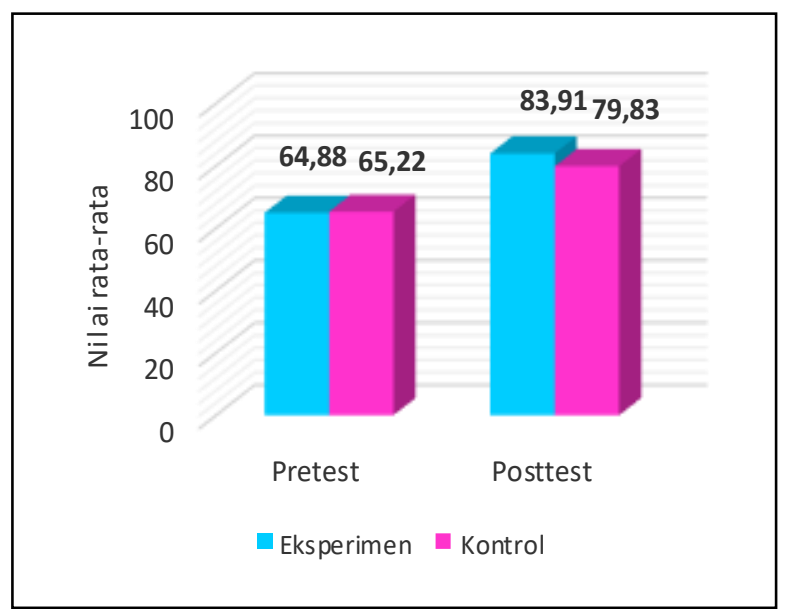

Gambar 1. Perbandingan Nilai Rata-rata Pretest dan Posttest Kelas Eksperimen dan Kontrol

\section{Uji Peningkatan Hasil Belajar Siswa}

Untuk mengetahui peningkatan hasil belajar siswa setelah diberikan perlakuan, maka data pretest dan data posttest dihitung gainnya atau selisih antara nilai posttest dengan nilai pretest, kemudian dihitung nilai gain ternormalisasi (N-Gain). Pada kelas eksperimen nilai rata-rata Gain lebih besar dibandingkan dengan nilai rata-rata Gain pada kelas kontrol. Hal ini ditunjukan dengan nilai rata-rata Gain pada kelas eksperimen yaitu sebesar 19,02 sedangkan nilai rata-rata Gain pada kelas kontrol yaitu sebesar 14,61. Dengan kata lain selisih peningkatan nilai pretest ke posttest kelas eksperimen lebih tinggi dibandingkan kelas kontrol. Peningkatan Gain yang tinggi kelas eksperimen dikarenakan pembelajaran sistem ekskresi menggunakan media model pembentukan urin, sehingga dengan adanya media tersebut siswa dapat lebih mudah memahami materi sistem ekskresi dibandingkan dengan pembelajaran konvensional. Pada kelas eksperimen Gain minimal yang diperoleh yaitu 
sebesar 13,00 dan Gain maksimal sebesar 27,00 dengan standar deviasi sebesar 06,00 sedangkan pada kelas kontrol Gain minimal yang didapat yaitu sebesar 06,00 dan Gain maksimal sebesar 26,00 dengan standar deviasi sebesar 04,37.

Berikut akan disajikan data perbandingan nilai $\mathrm{N}$-Gain kelas eksperimen dan kelas kontrol pada Gambar 2.

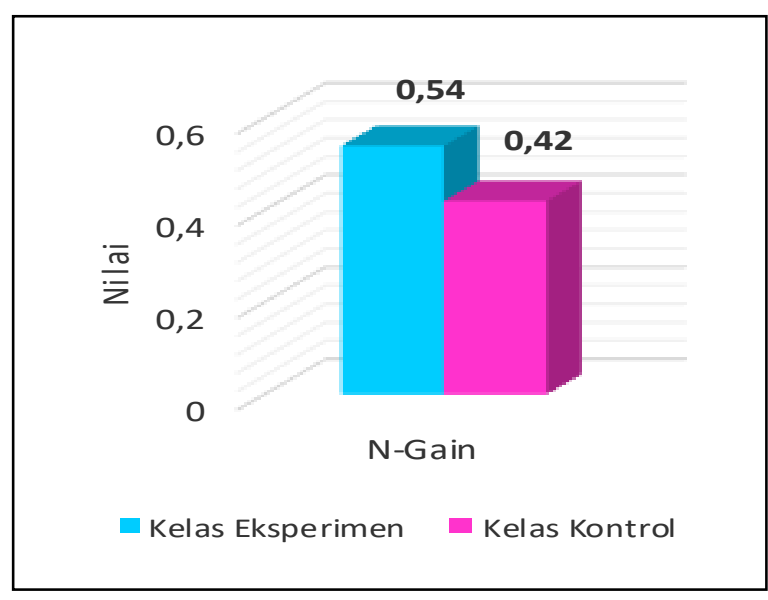

Gambar 2. Perbandingan Nilai N-Gain Kelas Eksperimen dan Kelas Kontrol

Walaupun secara kualitatif nilai rata-rata $\mathrm{N}$-Gain pada kelas eksperimen dan kelas kontrol sama-sama berada pada kategori sedang namun secara kuantitatif menunjukkan adanya perbedaan.

\section{Ketercapaian Kriteria Ketuntasan Minimal (KKM) Siswa}

Ketercapaian Kriteria Ketuntasan Minimal (KKM) di sekolah SMA Negeri 2 Cimahi yaitu sebesar 75 .

Tabel 2. Persentase Ketercapaian Belajar Siswa Kelas Eksperimen dan Kelas Kontrol

\begin{tabular}{lcccc}
\hline \multirow{2}{*}{$\begin{array}{c}\text { Komponen } \\
\text { Peninjau }\end{array}$} & \multicolumn{2}{c}{$\begin{array}{c}\text { Kelas } \\
\text { Eksperimen }\end{array}$} & \multicolumn{2}{c}{ Kelas Kontrol } \\
\cline { 2 - 5 } & Pretes & Posttes & Pretes & Posttes \\
\hline Jumlah & 36 & 36 & 36 & 36 \\
$\begin{array}{l}\text { Siswa } \\
\text { Batas }\end{array}$ & & & & \\
$\begin{array}{l}\text { Minimal } \\
\text { KKM }\end{array}$ & 75 & 75 & 75 & 75 \\
$\begin{array}{l}\text { Tuntas KKM } \\
\text { Tidak Tuntas }\end{array}$ & 5 & 29 & 6 & 25 \\
$\begin{array}{l}\text { KKM } \\
\text { Ketuntasan }\end{array}$ & 31 & 7 & 30 & 11 \\
$\begin{array}{l}\text { Belajar } \\
\text { Keterangan }\end{array}$ & $13 \%$ & $80 \%$ & $16 \%$ & $69 \%$ \\
\hline
\end{tabular}

Pembelajaran menggunakan media model pembentukan urin dikatakan efektif jika $75 \%$ hasil posttest memenuhi Kriteria Ketuntasan Minimal (KKM) sekolah. Hasil rekapitulasi nilai pretest dan posttest pada kelas eksperimen dan kelas kontrol siswa yang tuntas dan tidak tuntas KKM disajikan pada Tebel 3.

36 siswa pada kelas eksperimen pada saat pretes yaitu sebanyak 5 siswa tuntas KKM sedangkan 31 siswa lainnya tidak tuntas KKM. Berdasarkan pengalaman mengajar dan catatan lapangan di kelas XI IPA-7 kelima siswa tersebut tergolong siswa-siswa pintar dan rajin. Hal ini dibuktikan dengan nilai pretes mereka di atas KKM sekolah padahal sebelum dilaksanakannya pembelajaran, peneliti tidak memberitahu bahwa akan dilaksanakannya pengambilan data penelitian di kelas XI IPA-7.

\section{Tanggapan Mengenai Media Model Pembentukan Urin}

Tanggapan mengenai kelebihan dan kekuragan media model pembentukan urin yang diungkapkan oleh dosen ahli, guru, dan siswa. Sama halnya dengan pernyataan Asyad (2007), kelebihan dari media alat peraga nefron yaitu dapat menumbuhkan minat belajar siswa karena pelajaran menjadi lebih menarik, memperjelas makna bahan pelajaran sehingga siswa lebih mudah memahaminya, metode mengajar akan lebih bervariasi sehingga siswa tidak akan mudah bosan, serta dapat membuat lebih aktif melakukan kegiatan belajar seperti mengamati, melakukan dan mendemonstrasikan dan sebagainya. Sedangkan kekurangan dari media model pembentukan urin yaitu banyak menyita waktu pembelajaran, proses pembentukkan urin tidak ditunjukkan secara keseluruhan hanya proses filtrasi dan reabsorpsi saja yang dimunculkan, serta banyak kendala-kendala yang ditemukan ketika pelaksanaan diantaranya kebocoran alat, aliran selang macet. Hal tersebut dapat menghambat proses kelancaran belajar. 


\section{PEMBAHASAN}

Pelaksanaan kegiatan pembelajaran dalam penelitian telah sesuai dengan perencaan pada RPP karena peneliti terlibat langsung sebagai guru selama pembelajaran dan pembuatan RPP pun dibuat oleh peneliti sendiri, sehingga tahapan yang terdapat pada RPP dipahami betul oleh peneliti. Sejalan dengan pernyataan Getting (2009), guru tidak hanya menguasai sejumlah materi pembelajaran, namun penguasaan pendekatan dan metode pembelajaran yang tepat dan sesuai mutlak diperlukan. Untuk itu perlu kiranya para guru mampu menggunakan pendekatan dan metode yang tepat agar pembelajaran berjalan sesuai dengan perencanaan (Lissa, 2017). Namun untuk pengelolaan waktu menggunakan media model pembentukan urin masih kurang efektif karena menyita waktu yang telalu banyak untuk pembelajaran (Syintia et al., 2018). Penggunaan waktu yang terlalu lama ini dikarenakan banyak kendala yang dialami pada saat pelaksanaan pembelajaran (Sulastri et al., 2018). Kendala yang ditemukan pada saat pelaksanaan yaitu terletak pada medianya sendiri, diantaranya media banyak mengalami kebocoran, aliran air yang tersumbat, proses pembentukkan urin yang tidak lengkap, dan masih banyak lagi kendala yang ditemukan pada media ini. Pernyataan ini didukung oleh pernyataan siswa maupun guru pada lembar wawancara dan pada kuesioner. Hal ini sesuai dengan kelemahan media menurut Arsyad (2007) yang menyatakan bahwa banyak waktu yang diperlukan untuk persiapan. Persiapan dalam hal ini yaitu kesiapan media model pembentukan urin yang akan dijadikan media atau alat bantu guru selama pembelajaran berlangsung.

Rendahnya nilai pretes pada kedua kelas tersebut diduga karena beberapa faktor. Faktor pertama yaitu ketidaksiapan siswa dalam melaksanakan pretes. Ketidaksiapan ini diduga karena waktu belajar siswa dirumah sangat minim, karena banyaknya kegiatan diluar jam pelajaran seperti bimbingan belajar ditempat les setelah pulang sekolah ditambah dengan kegiatan sekolah lainnya yang dilaksanakan setelah jam bekajar selesai seperti ekstrakurikuler. Faktor kedua adalah beberapa soal-soal pada pretes diduga belum dipelajari dalam pembelajaran sebelumnya. Selain itu walaupun siswa sudah mempelajari materi sebelumnya, diduga sebagian siswa belum memahami betul materi tersebut. Hal ini menyebabkan siswa memiliki interpretasi yang berbeda-beda mengenai sistem ekskresi pada ginjal. Ketika dilaksanakannya demonstrasi menggunakan media model pembentukan urin siswapun tidak dapat menunjukkan bagian-bagian yang terdapat pada media model tersebut, diduga karena sebelumnya siswa belum pernah melihat dan menggunakannya.

Sejalan dengan hasil yang didapat pada saat pretes tidak terlalu tinggi, namun ada beberapa siswa yang mendapat nilai tinggi di atas KKM pada kelas eksperimen maupun kelas kontrol. Hasil tersebut sesuai dengan pandangan kontruksivisme menurut Widodo (2007) yang menyatakan bahwa siswa bukanlah kotak kosong yang hanya dapat diisi berbagai informasi, melainkan siswa memiliki pengetahuan awal yang didapat dari pengalaman dan lingkungannya. Peningkatan jumlah siswa kelas eksperimen yang tuntas KKM pada saat posttes yaitu sebanyak 29 dari 5 siswa yang tuntas KKM pada saat pretes. Dengan kata lain terdapat peningkatan 21 siswa yang tuntas KKM dari 5 siswa yang tidak tuntas KKM pada saat pretes. Menurut Asyhar (2012), menyatakan bahwa kriteria media pembelajaran yang baik yang perlu diperhatikan dalam proses pemilihan media yaitu ukurannya sesuai dengan lingkungan belajar. Disadari betul oleh peneliti bahwa ruang kelas XI IPA-7 cukup luas dan sudah memperkirakan bahwa harus digunakan dua media. Namun dalam pelaksanaannya penggunaan dua media memakan waktu yang tidak sedikit, hal ini dikarenakan siswa-siswa ingin mencoba dan memperagakannya. Disinilah mungkin peran guru yang harus pintar dalam mengelola kelas agar sesuai dengan apa yang telah dirancang pada RPP dengan pelaksanaanya. 
Kemampuan awal yang sama pada kelas eksperimen dan kelas kontrol memang harus terjadi dalam penelitian ini karena dengan kemampuan awal yang sama peneliti dapat mengukur kemampuan akhir siswa dengan diberikannya treatment (perlakuan) pada kelas eksperimen yaitu pembelajaran dengan menggunakan media model pembentukan urin dan kelas kontrol yang dijadikan sebagai kelas pembanding dengan menggunakan pembelajaran konvensional berupa ceramah ditambah slide Powerpoin, sehingga diakhir pembelajaran dapat terlihat pengaruh dari pemberian perlakuan tersebut. Jika hasil pretes kelas eksperimen dan kelas kontrol hasilnya adalah berbeda secara signifikan dengan kata lain pengetahuan awal siswa kelas eksperimen dan kelas kontrol berbeda, maka tidak dapat dilakukan pengukuran hasil akhir dengan diberikannya perakuan karena pengetahuan awalnya pun sudah terdapat perbedaan sehingga tidak bisa dijadikan ukuran seberapa berpengaruhnya pemberian perlakuan yang diberikan.

Peningkatan ini diduga terjadi akibat adanya perlakuan. Sehubungan dengan pendapat tersebut, Warsito (dalam Depdiknas, 2008) menyatakan bahwa hasil dari kegiatan belajar ditandai dengan adanya perubahan perilaku ke arah positif yang relatif permanen pada diri orang yang belajar. Wahidmurni et al., (2010) yang menyatakan bahwa seseorang dapat dikatakan telah berhasil dalam belajar jika ia mampu menunjukkan adanya perubahan dalam dirinya. Adanya peningkatan hasil belajar setelah diberikannya perlakuan menunjukkan bahwa siswa telah mengalami proses belajar. Menurut Sudjana (2010), hasil belajar adalah kemampuan yang dimiliki siswa setelah menerima pengalaman belajar. Pengalaman belajar yang dimaksud dalam penelitian ini yaitu pembelajaran dengan menggunakan media model pembentukan urin. Peningkatan hasil belajar pada kelas eksperimen lebih tinggi dibandingkan peningkatan hasil belajar pada kelas kontrol. Sejalan dengan pernyataan Hamalik (2006), hasil belajar yang diperoleh dapat diukur melalui kemajuan yang diperoleh siswa setelah belajar dengan sungguh-sungguh. Hasil belajar tampak terjadinya perubahan tingkah laku pada diri siswa yang dapat diamati dan diukur melalui perubahan sikap dan keterampilan. Perubahan tersebut dapat diartikan terjadinya peningkatan dan pengembangan yang lebih baik dibandingkan dengan sebelumnya. Media model pembentukan urin dapat meningkatkan ketertarikan siswa sehingga minat belajar siswa menjadi lebih baik dibandingkan dengan metode ceramah. Adapun Arsyad (2007) menyatakan bahwa alat peraga dapat menumbuhkan minat belajar siswa karena pelajaran menjadi lebih menarik serta dapat memperjelas makna bahan pelajaran sehingga siswa lebih mudah memahaminya.

Dalam hal ini tentu saja media model pembentukan urin yang digunakan peneliti bukanlah faktor mutlak yang menimbulkan pengalaman belajar siswa. Bagaimanapun suatu media itu dibuat tetaplah posisi media disini sebagai alat bantu guru untuk menyampaikan materi yang biasanya dianggap sulit bagi siswa. Senada dengan Djamarah et al., (2010) yang menyatakan bahwa kehadiran media mempunyai arti yang cukup penting dalam proses belajar mengajar, karena dalam kegiatan tersebut ketidak jelasan bahan dapat dibantu dengan menghadirkan media sebagai perantara, kerumitan bahan yang akan disampaikan kepada anak didik dapat disederhanakan dengan bantuan media, media dapat mewakili apa yang kurang mampu guru ucapkan melalui kata-kata atau kalimat tertentu bahkan, keabstarakan bahan dapat dikonkretkan dengan kehadiran media.

Menurut Slameto (2003), belajar dapat dipengaruhi oleh beberapa faktor internal dan eksternal. Faktor internal merupakan faktor-faktor yang berasal dari seseorang yang sedang belajar. Faktor internal meliputi faktor jasmaniah (kesehatan dan cacat tubuh), psikologi (intelegensi, perhatian, minat, bakat, motif, kematangan dan kesiapan) dan faktor kelelahan. Sedangkan faktor lainnya yaitu faktor eksternal 
merupakan faktor yang berasal dari luar, meliputi lingkungan keluarga (cara orang tua mendidik, relasi antar anggota keluarga, suasana rumah, keadaan ekonomi keluarga, perhatian orang tua, dan latar belakang kebudayaan), lingkungan sekolah (metode mengajar guru, kurikulum, relasi guru dengan siswa, relasi siswa dengan siswa, kedisiplinan di sekolah, alat pengajaran dan tugas rumah), serta lingkungan masyarakat (kegiatan siswa dalam masyarakat, teman bergaul dan bentuk kehidupan masyarakat lainnya).

\section{KESIMPULAN}

Efektifitas berdasarkan perencanaan dan pelaksanaan pembelajaran diukur melalui lembar observasi. Pelaksanaan kegiatan pembelajaran dengan menggunakan media model pembentukan urin efektif karena sesuai dengan perencanaan pembelajaran pada RPP yang telah dibuat. Namun untuk pengelolaan waktu tidak efektif karena menyita waktu yang telalu banyak untuk pembelajaran. Efektivitas berdasarkan hasil belajar siswa diukur melalui hasil pretest dan posttest dapat disimpulkan bahwa hasil belajar pada kelas eksperimen yang pembelajarannya menggunakan media model pembentukan urin lebih efektif dibandingan dengan kelas kontrol yang menggunakan pembelajaran konvensional berupa ceramah ditambah slide Powerpoin. Tanggapan terhadap media model pembentukan urin mendapatkan respon positif dari dosen ahli, guru dan siswa. Kelebihan media model pembentukan urin dapat memudahkan siswa dalam memahami materi proses pembentukkan urin, pembelajaran menjadi lebih atraktif, media praktis mudah dibawa, alat dan bahan mudah didapat dan tidak memerlukan biaya yang mahal. Kekurangan media model pembentukan urin yaitu media tidak ditunjukkan proses augmentasi, proses reabsorpsi tidak terlihat jelas, mudah terjadi kebocoran, aliran mudah tersumbat, jumlah media terbatas sehingga tidak terlihat jelas oleh semua siswa, dan memakan waktu yang cukup lama.

\section{REFERENSI}

Akhtar, A. et.al. (2010). Use of Media for Effective Instruction its Importance: Some Consideration. Journal of Elementary Education, 18 (1-2), hlm $35-40$

Arikunto, S. (2008). Prosedur Penelitian Suatu Pendekatan Praktek. Jakarta: Rhineka Cipta

Arsyad, A. (2007). Media Pembelajaran. Jakarta: PT Raja Grafindo Persada

Asyhar, R. (2012). Kreatif Mengembangkan Media Pembelajaran. Jakarta: Rhineka Cipta

Depdiknas. (2008). Bunga Rampai Keberhasilan Guru dalam Pembelajaran (SMA, SMK, dan $S L B)$. Jakarta: Depdiknas.

Djamarah, et al., (2010). Strategi Belajar Mengajar. Jakarta: Rineka Cipta

Getting, R. (2009). Menuju Guru Profesional dan Beretika. Yogyakarta: Graham Guru Printika

Hamalik, O. (2006). Proses Belajar Mengajar. Jakarta: PT Bumi Aksara

Koentjaraningrat. (1990). Metode-metode Penelitian Masyarakat. Jakarta: Pustaka Jaya

Lissa, L. (2017). Pengunaan Metode Giving Questions and Getting Answer terhadap Keaktifan Belajar Siswa SMA. BIOEDUSCIENCE, 1(1), 11-18. https://doi.org/10.29405/bioeduscience/1118111107

Meltzer, David, E. (2002). The Relationship between Mathematics Preparation and Conceptual Learning Gain in Physics: A Possible Hidden Variable in Diagnostic Pretest Scores. American Journal Physics. 70 (2), 1259-1267.

Sanjaya, W. (2007). Strategi Pembelajaran Berorientasi Standar Proses Pendidikan. Jakarta : Kencana Prenada Media

Slameto. (2010). Belajar dan Faktor-faktor yang Mempengaruhi. Jakarta: PT. Rhineka Cipta

Sudjana, N. (2005). Dasar-dasar Proses Balajar Mengajar. Bandung: Sinar Baru Algensindo

Sudjana, N. (2008). Penilaian Hasil Proses Belajar Mengajar. Bandung : Remaja Rosdakarya.

Sudjana, N. (2010). Penilaian Hasil Proses Belajar Mengajar (Cet. XV). Bandung: PT. Ramaja Rosdakarya.

Sugiyono. (2013). Metode Penelitian Pendidikan (Pendekatan Kuantitatif, Kualitatif dan R\&D). Bandung : Alfabeta

Sulastri, S., Akbar, B., Safahi, L., \& Susilo, S. (2018). Pengaruh Strategi Pembelajaran Critical Incident terhadap Keterampilan Analisis Siswa. Assimilation, 1(2), 77-81. 
Syintia, S., Akbar, B., Safahi, L., \& Susilo, S. (2018). Pengaruh Strategi Pembelajaran Relating, Experiencing, Applying, Cooperating, Transferring (REACT) terhadap Keterampilan Proses Sains Siswa. Assimilation, 1(2), 82-85.

Wahidmurni et al., (2010). Evaluasi Pembelajaran: Kompetensi dan Praktik. Yogyakarta: Nuha Letera

Widodo, A. (2007). Kontruksivisme dan Pembelajaran Sains. Jurnal Pendidikan dan Kebudayaan. 62 (13), 91-105 